\title{
Online Restorative Mediation Practices
}

\author{
Anton Iu. Konovalov* \\ State Budget Institution of Moscow City Center \\ of Psychological and Educational Assistance \\ Moscow, Russian Federation
}

Received 05.06.2020, received in revised form 01.09.2020, accepted 07.09.2020

\begin{abstract}
In 2019-2020, the COVID threat has changed ordinary life in many countries, including Russia. The fear of epidemic has affected people's condition and caused anxiety. Many people have found themselves isolated, unable to leave their homes and go to work, which further increased tensions. Those minors, who were shifted to distance learning format and forced to stay at home, also felt vulnerable. The specialists of the "helpline" note growing number of calls, including those related to family and childparental conflicts. The author organized a series of expert webinars, where the features of restorative practices and online mediation were discussed. The participants were practicing mediators, restorative justice specialists, children's helpline psychologists, members of the All-Russian Association for Restorative Mediation, and other specialists from Russia, Latvia and Ukraine. The results of these discussions have formed this research.

The most important result is that when it is impossible to use the means of face-toface communication, then the mediator (facilitator) needs to develop and master other methods and techniques for successful communication management, as well as trust and sincerity between the participants. Let us imagine it in a way: an author of a fiction book and a director of a film based on the same book will use different means to convey its meaning and states of the participants, but in the book through descriptions, and in the film through music and other cinematographic techniques, there will be a single content and the essence of the work.

The ideas and recommendations for online mediation described here can be useful not only for the isolation period, but also when working with those people who are difficult to access directly. For example, for those who live in closed institutions: hospitals, specialized educational institutions, temporary detention centers, penal institutions with remote location without an opportunity to come to a meeting, homeschooled students and their parents, if the parties do not want to communicate in direct contact with the members of network communities, etc. Moreover, Russia has already such experience and it needs to be expanded further.
\end{abstract}

Keywords: restorative mediation, restorative justice, restorative approach, conciliation services, online mediation, online restorative practices.

\footnotetext{
(C) Siberian Federal University. All rights reserved

* Corresponding author E-mail address: Konovalov-A@yandex.ru ORCID: 0000-0002-7077-0962
} 
Research area: education.

Citation: Konovalov, A.Iu. (2020). Online restorative mediation practices. J. Sib. Fed. Univ. Humanit. Soc. Sci., 13(9), 1510-1516. DOI: 10.17516/1997-1370-0659.

\section{Introduction}

On the 2000 initiative of Interregional Social Center "Judicial and Legal Reform", in Russia, restorative mediation and justice programs have been developing in the form of territorial and school reconciliation services (Konovalov, 2012) aimed at resolving conflict situations and preventing of juvenile delinquency. The importance of reconciliation services development in Russia is reflected in the following federal documents:

- "Methodological recommendations for creation and development of reconciliation services in educational institutions" (Ministry of Education and Science of the Russian Federation, 2015).

- "Methodological recommendations for mediation (reconciliation) network services in educational institutions and organizations for orphans and parentless children" (Ministry of Education of the Russian Federation, 2020).

The activities of school and local reconciliation services are based on the values of restorative justice, focused on the situation in educational organizations. They are formulated by the author on the website of the school reconciliation services (Konovalov, 2020).

Let us list them here:

- Restoration of the ability of the parties to conflict / violation to understand the consequences of the situation for themselves, their families and/or the other party.

- Responsibility of the offender to the victim (in case, if there is any offender) is to eliminate, as much as it possible by the offender himself, the harm (or strong offense) caused.

- Overcoming a victim state for those who have suffered harm, offense, aggression or injustice (if any) by expiating the damage caused to the victim and answering the victim's concerns by the offender and his/her relatives.

- Parties to the conflict situation (if they are "equal") assume responsibility for its settlement, excluding violence or further harm, end to mutual enmity, stabilize their relations and support responsible behavior.

- Planning by the parties to the conflict of their future (and their specific actions - who and what will do), which would allow to avoid such situations to repeat again in the future, stigmatize and reject any of the parties.

- Peers and respected people's support in moral guidelines and values activization, the absence of which has led to the conflict / violation. Support for positive changes and implementation of the concluded conciliation agreement (plan) on the part of relatives, peers, respected people and school community.

- Restoration of parents' responsible educational position towards the situation with their child.

These values are realized in the following restorative programs:

- "Circle of responsibility" - primary prevention, when there is no obvious conflict, it is highly to happen in the future (for example, in case of two classes merging, with the parents of $1^{\text {st }}$ grade pupils, with children and their parents when moving to a middle school, etc., or when there is tension among students and / or parents.

- "Reconciliation program" - resolving conflicts between schoolchildren (students).

- "Restorative mediation" - resolving conflicts between teachers and parents, as well as students and teachers.

- "Community circle" - resolving group conflicts in a classroom or within a group of parents by appealing to moral values, reaching agreement and mutual responsibility.

- "Family meetings" - coordination of the positions and interests of children, parents and teachers in relation to the educational process, parents' greater involvement and children' responsible behavior.

- "Harm reparation program" - secondary prevention and dealing with fights, theft, damage to property, etc. (including cases submitted 
to the court and the juvenile justice commissions).

- "School-parent council" (circle) - complex multilateral conflicts between all the parties of educational process (when children, parents, teachers, administration, education authorities, media, and others are involved in the conflict).

- Restorative approach to the classroom management - for educators and class teachers.

- Restorative approach to the management and development of educational organization for the administration and management and educational team.

These programs are conducted by a trained facilitator (or a team of facilitators) who first meet with each of the parties separately, prepare them for a joint meeting, and then organize a productive dialog, acting there as neutral intermediaries. As a rule, such meetings are held with a direct involvement of all parties to the conflict, but if it is impossible to meet faceto-face, one can hold it online.

\section{The problem of online using restorative practices and mediation and research method}

As the researches show, conflicts in the school environment occur quite often. And in 2019-2020, the threat of COVID - virus has also changed the usual way of life in Russia. Many people have found themselves being isolated, with no permission to leave their homes and go to work, which further increased the tension. The minors forced to a distance learning format and to stay at home - in a limited space - have also felt vulnerable. The specialists of the "helpline" informed us of increasing number of calls, including those related to family and child-parent conflicts. Thus, on the one hand, due to escalation of social tension and conflicts, some steps were required to resolve them, including mediation and restorative programs; on the other hand, they could only be carried out online, as required by the isolation regime. For most specialists it became a challenge, because online interaction differs from a face-to-face dialog - so much important in humanitarian practice.

In this situation, the author has organized a series of expert webinars, where the fea- tures of restorative practices and online mediation were discussed. The participants were practicing mediators, specialists in restorative justice, psychologists of the children's helpline, members of the All-Russian Association for Restorative Mediation and other specialists from Russia, Latvia and Ukraine. The results of these discussions have formed this article.

\section{Research results}

It is worth noting, that many specialists are somewhat afraid of a distant communicating (via telephone, Internet, by e-mailing, etc.). But let's think how much time we spent on phone or in texting with friends, helping them solve their problems and, usually, successfully. We can say that each of us has had a practice of support and assistance in a distance format, even if it is friendly, not professional. However, when we talk about an expert position, we must communicate with an unfamiliar person professionally, which causes difficulties. Many mediators note a lot of stress in online professional interaction. Perhaps, the human brain gets tired faster if it lacks information and cannot effectively understand and read information through other signals (timbre, speech rate, etc.). Therefore, young mediators quickly get tired at first, but as they gain experience, they start notice different nuances better, and, thus, this tension goes away.

What helps to understand a person behind the screen? As the seminar's participants say, first, it is camera. Moreover, not only the face should be visible on the screen, but, if possible, an image up to the chest, where one can see the body turns, hand gestures, etc. Some people are shy to turn on the camera - sometimes they do not have any make-up or there are any other members of the family and they do not want to show their flat - and therefore the participants connect online being in the car or walking in the park, which distracts both the person and other participants. Thus, while preparing for the meeting, we ask to be able to turn the video on, make a neutral background, and some programs like Zoom and Teams allow you to automatically create the background behind you. 
If it is impossible to turn the camera on and the person uses just his/her voice, then the mediator and other participants are guided by the speech rate, changes in the voice timbre, pauses and so on, which can signal emotional stress, attempts to avoid answering, etc. These techniques are mastered by, for example, specialists working on the "trust line", which allows them to monitor the state of a person by their voice.

If a person can only write in a chat (it also happens, for example, in case of a poor Internet connection), then additional information can be given by the speed of writing, misspellings and typos (some programs allow the facilitator to see what the person is writing and then erase or correct), quickness in answering, etc. All this is better to clear up at preliminary meetings.

There is another important aspect - safety. While in face-to-face mediation the parties usually come separately and then leave separately, then in isolation-time, the parties to the conflict are often locked up in one space (family conflicts, child-parental conflicts). Therefore, the mediator needs to make sure that they are safe: at least the parties should be in different rooms (better - in different places), do not talk to each other, and not leave their rooms after the end of the meeting for at least 15 minutes. The last requirement helps them to stay alone for a while and to comprehend the conversation.

In distance mediation, the issue of ensuring confidentiality also put certain difficulties. The mediator cannot remotely verify confidentiality; therefore, it is recommended that a part of the security and confidentiality requirements be included in the agreement on mediation procedure as the parties' responsibility, which they must ensure.

A strong Internet connection is a bottleneck for online media. It concerns not just the need for high-quality video and sound (poor sound confuses, and the information can be lost). No less relevant for the mediator is whether the person consciously leaves the mediation, or whether the connection is broken. If the person falls out of communication unexpectedly, then not only the mediator may have misunderstanding, but also the other party, which begins to interpret this communication gap in one's own way, and often not toward cooperation. Therefore, it is recommended to agree on a signal for the end of mediation (even if the person wants to interrupt it - so that he/she informs about it), as well as to think of an alternative way of communication (telephone, mail) in advance, so that the mediator has an opportunity to quickly make sure that everything is ok and whether the person will turn back to communication.

It is worth saying how difficult it is for the mediator to remotely read the signals of the participants, it is no less difficult for the participants to understand what is happening. Therefore, the mediator (facilitator) is required to provide the parties and participants with more support, attention and feedback than during normal communication.

Here are some techniques that the webinar participants shared to help establish communication:

- ask to indicate full names during registration (not user, etc.) so that the speaker's full name can be seen under the video;

- ask to turn off the microphones for those who are not speaking now, so that there is no background noise (the mediator can usually turn off the microphones, but it is better for the participants to be sure of this);

- set the time for communication and breaks, given that the participants start feel tired faster than in face-to-face communication;

- ask the participants to take water or tea;

- ask not to write in a general chat during the discussion (otherwise it creates parallel discussions and distracts the participants), not to experiment with the screen. If you have an urgent question, you can write to the mediator personally;

- make sure that everyone has their speakers, microphones and other equipment;

- the mediator writes in the chat the current stage of the meeting, topic or main question, so that everyone could read what is being discussed;

- show the participants how they can "raise their hand" if they want to express their 
voice, or to order the speakers - we gave the floor alphabetically and everyone knew who and after what time he/she would be given the mic;

- agree on whether the mediation (Circle) will be recorded, to whom and how it will be provided later. In most cases, we do not keep any records, but on training Circles, the recording is allowed with the consent of the participants.

To summarize, we note that "According to a study by Independent Mediators (UK) conducted in July 2020, more than $90 \%$ of those who have already participated in online mediation would agree to participate in the online procedure again and more than $40 \%$ of respondents would to take part in online mediation, provided that some of the participants are physically together during the process, while others are online", which indicates the willingness of the parties to accept such format (Independent Mediators, 2020).

\section{Conclusion}

Conducting restorative practices and mediation online is possible, but it requires readiness and certain competencies, both from the presenter (mediator) and the participants. As we believe, the traditional mediation of interests is more suitable for the online format than the restorative one, since in restorative mediation, there are more informal personal aspects (hostility suspension, repentance of the offender, victim restoration, etc.), which are difficult to actualize remotely. However, in restorative mediation, mixed formats are possible: pre- liminary meetings with the participants can be held online, while the general meeting - faceto-face.

As experience is being gained, the regulations for interaction and memos to the participants will be developed, which will spell out basic rules and conditions for working online, and there already are examples of such regulations.

Online restorative practices can be successfully used by the teachers in distant learning, when there are no strong conflicts, but it is important to maintain discipline and interaction with the class online. More information about the elements of restorative practices can be found in the materials of the website on school reconciliation services in the section for teachers and tutors (School reconciliation services / class teachers, 2020). It is also possible to work with adults, for example, an online restorative program "Circle of Responsibility" was worked out for teachers and parents in the schools of Moscow and in other regions during the pandemic period. Most of the Circle members has noted its effect, since many have found themselves in uncertainty, and communication was limited within the family, and the Circle has given the participants an opportunity to talk about the future, make and agree on plans, take responsibility and control over what is happening.

The author thanks all the participants in the webinars of the All-Russian Association for Restorative Mediation, who contributed to this article by their speeches and discussions.

\section{References}

Hasinoff, E.A., Gibson, A.D., Salekhi, N. (2020). The Promise of Restorative Justice in Addressing Online Harm. Available at: www.brookings.edu/techstream/the-promise-of-restorative-justice-in-addressing-online-harm/?fbclid=IwAR1goRtpjMNj7Wm_K2F62_JzQRaex5cYkatLvuQjGJoxpKxJNTatF1uvxqA (Accessed August 7, 2020)

Independent Mediators - Online Mediation Survey Results (2020). Available at: www.independentmediators.co.uk/independent-mediators-online-mediation-survey-results-july-2020 (Accessed August 7, 2020).

Konovalov, A.Iu., Belonogova, E.V. (2017). Model'noe opisanie programmy "Semeinaia konferentsiia" dlia spetsial'nykh uchebno-vospitatel'nykh uchrezhdenii: Metodicheskoe posobie [Pattern Description of "Family Conference" program for Specialized Educational Institutions: Methodical Guidelines]. Moscow, Obshchestvenniy Tsentr "Sudebno-pravovaya reforma". 
Konovalov, A.Iu. (2012). Shkol'naia sluzhba primireniia i vosstanovitel'naiia kul'tura vzaimootnoshenii: prakticheskoe rukovodstvo [School Conciliation Services and Restorative Culture of Interrelationship: Practical Guide]. Moscow, Obshchestvenniy Tsentr "Sudebno-pravovaya reforma".

Malovichko, I.S., Golustiants, O.A., Shefatova, L.P. (2016). Programma chelnochnoi vosstanovitel'noii mediatsii mezhdu nesovershennoletnimi pravonarushiteliami i postradavshimi ot ikh deistvii "pis'mo obidchika postradavshemu o zaglazhivanii vreda» i ee realizatsiiia v zakrytykh uchrezhdeniakh. Metodicheskoe posobie [The Program of Circular Restorative Mediation between Minor Offenders and Victims "A Letter of Expiation" and Its Implementation in Closed Institutions: Methodological Guide]. Available at: http://www.8-926-145-87-01.ru/wp-content/uploads/2017/02/2016_Методика-челночной-медиации-вЦВСНП.doc (accessed 7 August 2020).

Metodicheskie rekomendatsii po razvitiiu seti sluzhb mediatsii/primireniia $v$ obrazovatel'nykh organizatsiiakh, organizatsiiakh dlia detei-sirot i detei, ostavshikhsia bez popecheniia roditelei [Methodological Recommendations on Development of Mediation/Conciliation Services Network in Educational Institutions, Houses for Orphans and Parentless Children] (2020). Available at: https://yadi.sk/i/1oBseRnwQQ-vGA (Accessed August 7, 2020).

Metodicheskie rekomendatsii po sozdaniiu i razvitiiiu sluzhb primireniia $v$ obrazovatel'nykh organizatsiiakh [Methodological Recommendations on Creation and Development of Conciliation Services in Educational Institutions] (2015). Available at: www.8-926-145-87-01.ru/wp-content/uploads/2018/01/ merged-1-1.pdf (Accessed August 7, 2020).

Sait shkol'nykh sluzhb primirenii a [School Cinciliation Services Website] (2020). Available at: www. школьные-службы-примирения.рф (Accessed August 7, 2020)

Vebinar "Tekhnologii profilaktiki i razresheniî a slozhnykh situat siü pedagogicheskogo vzaimodeŭstvii a" [Webinar: Preventing and Resolving Troubles in Pedagogical Interaction] (2020). Available at: www. facebook.com/permalink.php?story_fbid=1539475252881001\&id=100004556222519 (Accessed August 7, 2020).

Vosstanovitel'niy podkhod v rabote klassnogo rukovoditeli a [Restorative Approach in Class Teaching] (2020). Available at: www.8-926-145-87-01.ru/создать-службу-примирения/вп-в-работе-классногоруководителя (Accessed August 7, 2020)

\title{
Практики восстановительной медиации в формате онлайн
}

\section{А.Ю. Коновалов}

ГБУ «Городской психолого-педагогический центр Департамента образования и науки города Москвы» Российская Федерачия, Москва

\begin{abstract}
Аннотация. В 2019-2020 гг. угроза заражения вирусом COVID изменила привычный уклад жизни во многих странах, включая Россию. Страх людей перед эпидемией отразился на их состоянии и тревожности. Многие люди оказались в изоляции, без возможности покидать свое жилище и выходить на работу, что вдобавок увеличило напряженность. В уязвимую ситуацию попали и переведенные на дистанционный формат обучения несовершеннолетние, которые вынуждены были находиться в ограниченном пространстве дома. Работающие на «телефоне доверия» специалисты сообщали нам об увеличении числа обращений, в том числе по семейным и детско-родительским конфликтам. В это время автором была организова-
\end{abstract}


на серия экспертных вебинаров, на которых обсуждались особенности восстановительных практик и медиации в онлайн-формате. Участниками были практикующие медиаторы, специалисты по восстановительному правосудию, психологи детского «телефона доверия», члены Всероссийской ассоциации восстановительной медиации и другие специалисты из России, Латвии и Украины. Результаты этих обсуждений легли в основу данной статьи.

Основной вывод заключается в том, что когда невозможно использовать средства очной коммуникации, то ведущему (медиатору, фасилитатору) необходимо разрабатывать и осваивать иные методы и приемы для эффективного управления коммуникацией, а также достигать доверия и искренности между участниками. Можно предложить такой образ: автор художественной книги и режиссер фильма по этой же книге будут использовать разные средства для передачи ее смысла и состояний участников, но и в книге через описания, и в фильме через музыку и другие приемы кинематографа будут передаваться единое содержание и суть произведения.

Собранные здесь идеи и рекомендации по проведению медиации в режиме онлайн могут быть полезны не только при работе в режиме изоляции, но и в работе с теми людьми, к которым затруднен непосредственный доступ. Например, находящихся в закрытых учреждениях: больницах, СУВУ, центрах временного содержания, местах заключения, находящихся в отдалении без возможности приехать лично на встречу, детей на домашнем обучении и их родителей, при нежелании сторон коммуницировать в непосредственном контакте, с участниками сетевых сообществ и т.д. Тем более что в России такой опыт уже есть и его надо расширять.

Ключевые слова: восстановительная медиация, восстановительное правосудие, восстановительный подход, службы примирения, медиация онлайн, восстановительные практики онлайн.

Научная специальность: 13.00.00 - педагогические науки. 